\title{
Determination and residual characteristic of alkylphenols in household food detergents of Taiwan
}

\author{
Yi-Ping Pan, Shih-Wei Tsai * \\ Institute of Environmental Health, College of Public Health, National Taiwan University, No. 17, Xuzhou Road, Taipei 100, Taiwan
}

\section{A R T I C L E I N F O}

\section{Article history:}

Received 10 December 2008

Received in revised form 11 March 2009

Accepted 16 March 2009

Available online $\mathrm{xxxx}$

\section{Keywords:}

Food detergents

Alkylphenols

Exposure

Taguchi method

Gas chromatography

\begin{abstract}
A B S T R A C T
The non-ionic surfactants are mostly composed of alkylphenols for the ingredients of synthetic food detergents. Due to the ability to mimic hormones, it has been noticed that the exposures of alkylphenols might cause a variety of adverse effects. To assess the associate risks from possible exposures, concentra-

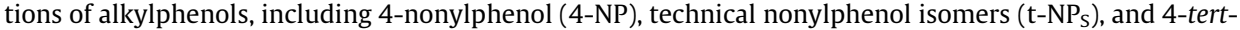
octylphenol (4-t-OP), in household food detergents of Taiwan were determined. Gas chromatography with mass spectrometer (GC/MS) was used to analyze alkylphenols in samples. The Taguchi experimental design was utilized to study the possible factors that might affect the residual characteristics of alkylphenols from detergents on dishware and fruits. By the analysis of variance, the orders of importance of different parameters were determined. The results showed that the concentrations of alkylphenols in food detergents ranged from $1.71 \times 10^{-5}$ to $2.13 \times 10^{-3}$ (APs/detergent, $\mathrm{mg} \mathrm{g}^{-1}$ ). For residual characteristics, the cleaning temperature was found to be the only significant factor that will affect the 4-t-OP left on the dishware, while the concentrations of detergents used will affect the left of t-NPs and 4-NP on dishware as well. On the other hand, the varieties of fruits, the concentrations of detergents, and the concentrations of alkylphenols were found to have significant effects for the t-NPs left on fruits. As for the exposure assessments, the maximum dose of APs exposures from the use of household food detergents in Taiwan was also estimated in the study.
\end{abstract}

(c) 2009 Elsevier Ltd. All rights reserved.

\section{Introduction}

The major components of detergents are surfactants, which consist of a polar head group and a nonpolar hydrocarbon tail (Ying, 2006). There are three types of surfactants, including anionic, non-ionic and cationic (Tsai et al., 2008). The world demand of synthetic surfactants in 2003 was estimated at more than 9 million tons (Lara-Martin et al., 2008).

As for the ingredients of synthetic food detergents, the non-ionic surfactants are mostly composed of alkylphenols (APs), such as nonylphenol (NP) and octylphenol (OP) (Ying, 2006). APs are chemical compounds used primarily to manufacture APEs, which have been used for more than 50 years. Nonylphenol ethoxylates account for $80 \%$ of the APE produced, while the remaining $20 \%$ is basically octylphenol ethoxylates (Renner, 1997). In the manufacturing process, APs are produced through alkylation of phenol with octene or nonene in the presence of an acid catalyst, preferentially alkylates at the para position of phenol, and then APEs are produced by the ethoxylation of APs (European Commission, 2002). APEs are discharged into wastewater treatment facilities or directly released into the environment (Ying et al., 2002). It

\footnotetext{
* Corresponding author. Tel.: +886 23322 8097; fax: +886 223516289.

E-mail address: shihweitsai@ntu.edu.tw (S.-W. Tsai).
}

has been reported that the degradation of APEs in the environment will generate more persistent shorter chain APEs and APs under anaerobic conditions (Jobling et al., 1996; Renner, 1997).

NP and OP have attracted a lot of scientific attention because of their estrogenic effects and ability to bioaccumulate in aquatic organisms (Ying, 2006). Because they mimic hormones, APs can interact with the estrogen receptor as the endocrine-disrupting chemicals (EDCs), and cause a variety of adverse effects in ecology (Harris et al., 2000; Gutendorf and Westendorf, 2001; Madsen et al., 2004). The European Union has recently legislated limitations (Directive 2003/53/EC) for the use of APEs and APs in industrial applications (EU, 2003). On the other hand, a voluntary ban about domestic detergents has been agreed by the major manufacturers of detergents in some countries (European Commission, 2002).

Many researchers have reported on the wide occurrence of APs in the environment matrices, included air (Xie et al., 2006), surface water (Cheng et al., 2006), wastewater and tap water (Diaz et al., 2002), and sediment (Peng et al., 2006). Besides, the concentrations of APs and APEs in some products for human consumption also have been determined (Cheng and Ding, 2002; Latorre et al., 2005; Sakurai et al., 2005).

APEs is one of the major classes of non-ionic surfactants used and produced in Taiwan (exceed 130000 metric tons in 1996 (Shih, 
1997). It was reported that APEs were detected in $41 \%$ of 90 household detergents at concentrations from $0.2 \%$ to $21 \%$ in Taiwan (Cheng and Ding, 2002).

The exposure to low level dosage of APs via daily activities is suspected to be associated with health risks (Soto et al., 1995). However, information regarding the amounts of APs in household food detergents is limited in the existing literature. Therefore, the possible exposure to APs from the use of food detergent remains unknown. Besides, it is also unclear if different conditions of detergents using processes will affect the levels of APs left on the dishware or fruits.

Determination of the residual characteristics for triclosan in household food detergent has been reported previously (Tsai et al., 2008). Orthogonal designs of experiments and Taguchi method were employed to determine the factors that might affect the level of triclosan left on dishware and fruits after the use of food detergents (Tsai et al., 2008). In this research, the design was extended and the residual characteristics of APs, including 4-nonylphenol (4-NP), technical nonylphenol isomers (t-NPs) and 4-tertoctylphenol (4-t-OP), in food detergents of Taiwan were determined (Table 1 shows the physical and chemical properties of the selected alkylphenols). The concentrations of APs in various household food detergents were also investigated. Besides, the maximum dose of APs exposures from the use of household food detergents in Taiwan was estimated in the study as well.

\section{Experimental}

\subsection{Reagents and chemicals}

Purity grade $\geqslant 98 \%$ 4-nonylphenol (4-NP), technical nonylphenol isomers ( $t-N P s$, purity drage $\geqslant 94 \%$ ) and HPLC grade methanol (purity $\geqslant 99.9 \%$ ) were obtained from Riedel de Häen (Seelze, Germany) while 4-t-octylphenol (4-t-OP, purity grade $\geqslant 98.7 \%$ ) was purchased from Aldrich (Milwaukee, WI, USA). Additionally, Phenanthrere-d10 (purity grade $\geqslant 99.5 \%$ ) was from Supelco (Bellefonte, PA, USA) and used as the internal standard in GC/MS analysis. Deionized water was from the Barnstead NANOpure Infinity Water Purification Systems (Dubuque, IA, USA). Stock standard solutions of each AP were prepared by dissolving the compounds in methanol. All solutions were stored in the dark at $4{ }^{\circ} \mathrm{C}$ until use.

\subsection{Calibration and quantitations}

Stock solutions of each analyte $\left(100 \mathrm{mg} \mathrm{L}^{-1}\right)$ were prepared in methanol, respectively. These solutions were then used to prepare standard solutions of 4-t-OP $\left(0.001-0.1 \mathrm{mg} \mathrm{L}^{-1}\right), 4-\mathrm{NP}(0.001-$ $\left.0.099 \mathrm{mg} \mathrm{L}^{-1}\right)$, and t-NPs $\left(0.02-2.0 \mathrm{mg} \mathrm{L}^{-1}\right)$. The internal standard, Phenanthrene-d10 (Hoai et al., 2003), was spiked to the standard solutions with final concentration equaled $0.08 \mathrm{mg} \mathrm{L}^{-1}$. Each standard solution was injected in triplicate into the chromatograph.
The peak area ratio of analytes and internal standard were plotted against the corresponding APs concentrations to obtain the calibration graph.

To determine the precision and accuracy of the analytical method, spiked APs samples $\left(0.01 \mathrm{mg} \mathrm{L}^{-1}\right.$ for $4-t-\mathrm{OP}$ and $4-\mathrm{NP}$; $0.50 \mathrm{mg} \mathrm{L}^{-1}$ for t-NPs) of detergents were analyzed seven times. The relative standard deviation (R.S.D.) and accuracy were then calculated. Another spiked samples (the first points of the calibration lines; i.e., $0.001 \mathrm{mg} \mathrm{L}^{-1}$ for 4-t-OP and 4-NP, and $0.02 \mathrm{mg} \mathrm{L}^{-1}$ for t-NPs) were also analyzed seven times to determine the method detection limits (MDLs), since they were found to be the breaks in the slopes of the standard curves (US CFR 40, Part 136, Appendix B).

\subsection{Samples collection and preparation}

Total 75 different household food detergent samples were purchased from major supermarkets and local stores from northern to southern Taiwan with various compositions and were representative of the typical food detergent samples in Taiwan. However, dishwasher detergent was not included in this study because it was not commonly used nationwide.

The food detergent samples collected were first diluted to $6.7 \mathrm{~g} \mathrm{~L}^{-1}$ with methanol (CNS Standards, 2000). Afterwards, the diluted solution was directly analyzed by gas chromatography with mass spectrometry (GC/MS) to determine the APs in the samples.

After the measurements, food detergents with no alkylphenols detected were selected as the media for further determinations of residual characteristics. Regarding the procedure of residual analysis for dishware washing, the method established previously was adopted (Tsai et al., 2008). In brief, an orthogonal array experiment (Taguchi experiment) (Hicks, 1999) with variation of eight experimental parameters was constructed. On the other hand, as for the evaluation of residuals on different kinds of fruits, orthogonal array experiment with variation of four experimental parameters was also constructed based on the method reported previously (Tsai et al., 2008).

Design-Expert 7.0 (Stat-Ease, Minneapolis, MN, USA) (Montgomery, 2001; Alben, 2002) was used to model the process and predict optimum conditions to minimize the residue of food detergents either on dishware or fruits.

\subsection{Instrumentation}

All analyses were performed with a Hewlett-Packard 6890 gas chromatograph equipped with a 5973 mass-selective detector from Angilent (Santa Clara, CA, USA). Equity ${ }^{\mathrm{TM}} 5(30 \mathrm{~m} \times 0.25 \mathrm{~mm}$ i.d., $0.25 \mu \mathrm{m}$ film thickness) capillary column from Supelco (St. Louis, MO, USA) was used. Analytical method reported previously for the measurements of APs were modified as follows (Pan and Tsai, 2008): transfer line and ion source temperature were set at $290{ }^{\circ} \mathrm{C}$

Table 1

Physical and chemical properties of selected alkylphenols (UKEA, 2005; Environment Canada, 2001).

\begin{tabular}{|c|c|c|c|}
\hline Compounds & 4-tert-Octylphenol & Nonylphenol technical mixture & 4-Nonylphenol \\
\hline Abbreviation & $4-t-O P$ & $\mathrm{t}-\mathrm{NPs}$ & 4-NP \\
\hline CAS registry no. & $140-66-9$ & $84852-15-3$ & $104-40-5$ \\
\hline Structure & & Unspecified, mixed isomers & \\
\hline Formula & $\mathrm{C}_{14} \mathrm{H}_{22} \mathrm{O}$ & $\mathrm{C}_{15} \mathrm{H}_{24} \mathrm{O}$ & $\mathrm{C}_{15} \mathrm{H}_{24} \mathrm{O}$ \\
\hline M.W. (g mole $\left.{ }^{-1}\right)$ & 206.32 & 220.34 & 220.34 \\
\hline Boiling point $\left({ }^{\circ} \mathrm{C}\right)$ & $280-302$ & $295-320$ & $293-297$ \\
\hline
\end{tabular}


and $230{ }^{\circ} \mathrm{C}$, respectively. Injection port temperature was $270{ }^{\circ} \mathrm{C}$ with splitless mode. The temperature program was as follows: initial oven temperature was $50^{\circ} \mathrm{C}$ for $1 \mathrm{~min}$, increased to $170{ }^{\circ} \mathrm{C}$ at a rate of $24{ }^{\circ} \mathrm{C} \mathrm{min}-1$, increased by $10^{\circ} \mathrm{C} \mathrm{min}^{-1}$ up to $250{ }^{\circ} \mathrm{C}$, and held for $1 \mathrm{~min}$. Helium for GC/MS was $99.9995 \%$ supplied from Qiaoyi (Taipei, Taiwan). All the work was carried out in constant flow mode set at $1.0 \mathrm{ml} \mathrm{min}{ }^{-1}$. Qualitative and quantitative analyses were operated in the selected ion monitoring (SIM) mode.

\section{Results and discussion}

\subsection{Determinations of alkylphenols}

The target analytes of this research included 4-tert-octylphenol (4-t-OP), 4-nonylphenol (4-NP), and technical nonylphenol isomers (t-NPs). Standard solutions in methanol ranged from $0.001-0.1 \mathrm{mg}$ $\mathrm{L}^{-1}, \quad 0.001-0.099 \mathrm{mg} \mathrm{L}^{-1}$, and $0.02-2.0 \mathrm{mg} \mathrm{L}^{-1}$ were prepared for 4-t-OP, 4-NP, and t-NPs, respectively. The calibration lines established were $Y=(7.87 \pm .02) X+(0.012 \pm 0.0011)$ with $R^{2}=$ $0.99, Y=(5.19 \pm 0.05) X+(0.001 \pm 0.002)$ with $R^{2}=0.99$, and $Y=$ $(3.69 \pm 0.06) X+(0.291 \pm 0.065)$ with $R^{2}=0.99$, for $4-t-O P, 4-N P$, and t-NPs, respectively, where $Y$ and $X$ equaled peak area and concentration of APs.

Fig. 1 shows a typical sample chromatogram where longer retention time was observed with the increase of carbons among these alkyl groups. To determine the precision and accuracy of

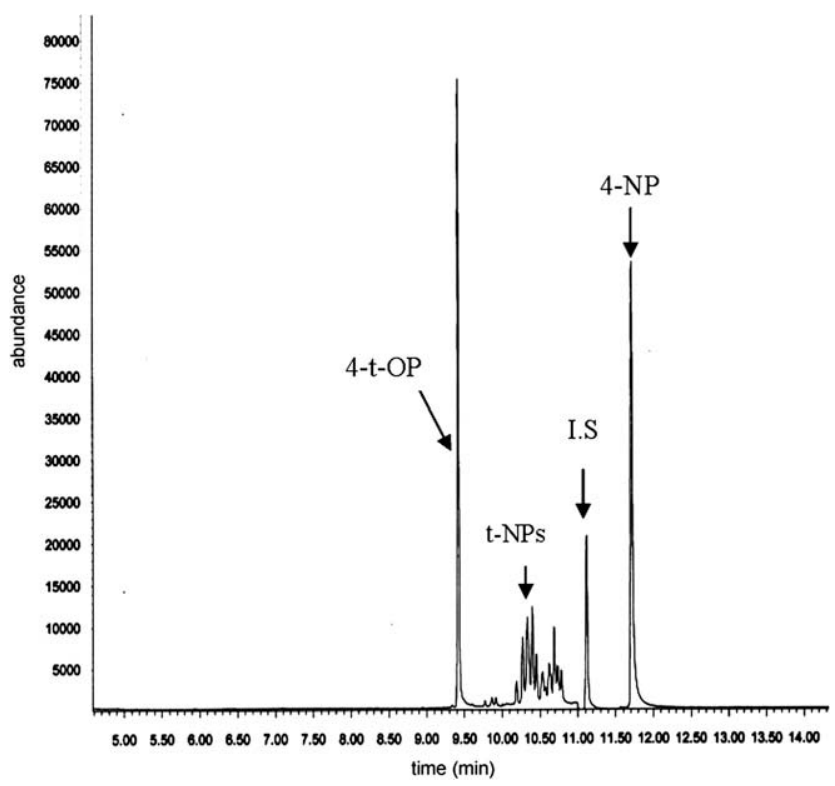

Fig. 1. Typical GC/MS chromatogram from the sample injection. the analytical method, spiked samples of detergents were analyzed seven times as mentioned above. The relative standard deviations were found to be less than $3 \%$, and the recoveries were $100 \pm 5 \%$. Another spiked sample was also analyzed seven times to determine the detection limits, and the MDLs were found to be 0.53 , 0.36 , and 4.90 (APs/methanol, $\mathrm{ng} \mathrm{mL}^{-1}$ ) for 4-t-OP, 4-NP and t-NPs, respectively.

\subsection{Distribution of alkylphenols in detergent samples}

The described analytical method was used to investigate the concentrations of APs in food detergents. As shown in Table 2, the concentrations determined ranged from $1.71 \times 10^{-5}$ to $2.13 \times 10^{-3}$ (APs/detergent, $\mathrm{mg} \mathrm{g}^{-1}$ ).

Among the 75 food detergent samples collected, none of them was clearly specified with APs or APEs contents by the manufactures, but mostly only with 'surfactants', 'non-ionic surfactants' or 'anionic surfactant' on the labels. As shown in Table 2, 17.3\% $(13 / 75)$ of the food detergent samples collected were labeled to contain non-ionic surfactant. Among them, 84.6\% (11/13) and $53.8 \%(7 / 13)$ were found to contain t-NPs and 4-NP, respectively. On the other hand, $65.3 \%$ (49/75) of the food detergent samples collected were only labeled to contain surfactant (without specifying the ingredients), and $65.3 \%$ (32/49) and 51.0\% (25/49) of them were also found to contain t-NPs and 4-NP, respectively. In overall, $5.3 \%(4 / 75)$ of the food detergent samples collected in Taiwan were found to contain $4-t$-OP, while $66.7 \%(50 / 75)$ and $46.7 \%(35 / 75)$ were observed to have t-NPs and 4-NP, respectively.

\subsection{Residual characteristics of alkylphenols on dishware from food detergents}

Fractional factorial design approaches (Montgomery, 2001) were applied to study the main factors that might affect the residual characteristics when using food detergents. As shown in Table 3 , factors that might affect the residue of APs from food detergents on dishware were investigated.

To determine the residual characteristics of APs on dishware from food detergents, ANOVA test, including all factors was performed first. As shown in Fig. 2, the normal probability plot of residuals showed the model did not have acceptable adequacy for 4-t-OP. Backward elimination procedure was then performed by the Design-Expert 7.0 and only the cleaning temperature was kept in the model $(p=0.026)$. Further residual analysis showed the normality was improved obviously (Fig. 3). The results suggested that the 4-t-OP left on the dishware will decrease as the cleaning temperature of water used increased.

For 4-NPs, the normal probability plot of residual also showed the model did not have acceptable adequacy. Backward elimination procedure was performed as well and only the concentrations of detergents was kept in the model $(p=0.0047)$. The results

Table 2

Alkylphenols found in household food detergents of Taiwan.

\begin{tabular}{|c|c|c|c|c|}
\hline \multirow[t]{2}{*}{ Types of surfactants } & \multirow[t]{2}{*}{ Number of samples } & \multicolumn{3}{|c|}{ Types of APs detected in food detergents } \\
\hline & & $4-t-O P$ & t-NPs & $4-N P$ \\
\hline Surfactant ${ }^{\mathrm{a}}$ & 49 & $1 / 49(2.0 \%)^{b}$ & $32 / 49(65.3 \%)$ & $25 / 49(51.0 \%)$ \\
\hline Non-ionic surfactant & 13 & $0 / 13(0.0 \%)$ & $11 / 13(84.6 \%)$ & $7 / 13(53.8 \%)$ \\
\hline Anionic surfactant & 6 & $2 / 6(33.3 \%)$ & $3 / 6(50.0 \%)$ & $0 / 6(0.0 \%)$ \\
\hline Others & 7 & $1 / 7(14.3 \%)$ & $4 / 7(57.1 \%)$ & $3 / 7(42.9 \%)$ \\
\hline Total & 75 & $4 / 75(5.3 \%)$ & $50 / 75(66.7 \%)$ & $35 / 75(46.7 \%)$ \\
\hline Conc. ranges (APs/detergent; $\mathrm{mg} \mathrm{g}^{-1}$ ) & & n.d. $-1.71 \times 10^{-5 c}$ & n.d. $-2.13 \times 10^{-3}$ & n.d. $-7.63 \times 10-5$ \\
\hline
\end{tabular}

\footnotetext{
${ }^{a}$ Product just labeled containing surfactant without further specification.

b $2 \%(1 / 49)$ of the detergent samples which were only labeled containing surfactant were detected to contain 4-t-OP.

c n.d.: not detectable.
} 
Table 3

$\mathrm{L}_{18}\left(3^{6} \times 2^{2}\right)$ orthogonal array for residual characteristics determinations on dishware.

\begin{tabular}{|c|c|c|c|c|c|c|c|c|c|c|c|c|}
\hline \multirow[t]{2}{*}{ Trial } & \multirow[t]{2}{*}{$\begin{array}{l}\text { Immersion } \\
\text { temperature } \\
\left({ }^{\circ} \mathrm{C}\right)\end{array}$} & \multirow[t]{2}{*}{$\begin{array}{l}\text { Cleaning } \\
\text { temperature } \\
\left({ }^{\circ} \mathrm{C}\right)\end{array}$} & \multirow[t]{2}{*}{$\begin{array}{l}\text { Dishware } \\
\text { materials }\end{array}$} & \multirow[t]{2}{*}{$\begin{array}{l}\text { Detergent } \\
\text { conc. }^{\mathrm{a}}\left(\mathrm{g} \mathrm{L}^{-1}\right)\end{array}$} & \multirow[t]{2}{*}{$\begin{array}{l}\text { Alkylphenols } \\
\text { conc. }^{\text {b }}\end{array}$} & \multirow[t]{2}{*}{$\begin{array}{l}\text { Immersion } \\
\text { time (min) }\end{array}$} & \multirow[t]{2}{*}{$\begin{array}{l}\text { Cleaning } \\
\text { time }(\mathrm{s})\end{array}$} & \multirow[t]{2}{*}{$\begin{array}{l}\text { Sampling } \\
\text { temperature } \\
\left({ }^{\circ} \mathrm{C}\right)\end{array}$} & \multicolumn{4}{|c|}{$\begin{array}{l}\text { Note: APs in deionized water } \\
\text { before the test vs. APs left on } \\
\text { dishware ( } \mu \mathrm{g} \mathrm{APs} \mathrm{L}^{-1} \text { deionized water) }\end{array}$} \\
\hline & & & & & & & & & APs & $4-t-O P$ & 4-NP & t-NPs \\
\hline 1 & 25 & 25 & Porcelain & 6.7 & 0.5 Fold & 5 & 15 & 4 & 71.36 & 7.13 & 2.38 & 12.13 \\
\hline 2 & 25 & 25 & Glass & 33.5 & 5 Fold & 10 & 30 & 25 & $35.67 \times 10^{2}$ & 9.61 & 2.33 & 9.93 \\
\hline 3 & 25 & 25 & Melamine & 67 & 1 Fold & 20 & 45 & 90 & $14.27 \times 10^{2}$ & 8.30 & n.d. & 9.61 \\
\hline 4 & 25 & 60 & Porcelain & 33.5 & 1 Fold & 10 & 45 & 4 & $7.14 \times 10^{2}$ & 3.06 & 2.21 & 10.68 \\
\hline 5 & 25 & 60 & Glass & 67 & 0.5 Fold & 20 & 15 & 25 & $7.14 \times 10^{2}$ & 2.35 & 3.71 & 13.19 \\
\hline 6 & 25 & 60 & Melamine & 6.7 & 5 Fold & 5 & 30 & 90 & $7.14 \times 10^{2}$ & 3.34 & 1.12 & 12.16 \\
\hline 7 & 25 & 60 & Porcelain & 67 & 5 Fold & 10 & 15 & 90 & $71.36 \times 10^{2}$ & 3.63 & n.d. & 8.18 \\
\hline 8 & 25 & 60 & Glass & 6.7 & 1 Fold & 20 & 30 & 4 & $1.43 \times 10^{2}$ & 2.16 & n.d. & 9.58 \\
\hline 9 & 25 & 60 & Melamine & 33.5 & 0.5 Fold & 5 & 45 & 25 & $3.55 \times 10^{2}$ & 1.46 & n.d. & 12.15 \\
\hline 10 & 60 & 25 & Porcelain & 67 & 1 Fold & 5 & 30 & 25 & $14.27 \times 10^{2}$ & 3.99 & n.d. & 10.96 \\
\hline 11 & 60 & 25 & Glass & 6.7 & 0.5 Fold & 10 & 45 & 90 & 71.36 & n.d. & n.d. & 9.72 \\
\hline 12 & 60 & 25 & Melamine & 33.5 & 5 Fold & 20 & 15 & 4 & $35.68 \times 10^{2}$ & 6.53 & n.d. & 9.88 \\
\hline 13 & 60 & 60 & Porcelain & 6.7 & 5 Fold & 20 & 45 & 25 & $7.14 \times 10^{2}$ & 5.13 & n.d. & 13.22 \\
\hline 14 & 60 & 60 & Glass & 33.5 & 1 Fold & 5 & 15 & 90 & $7.14 \times 10^{2}$ & n.d. & n.d. & 7.15 \\
\hline 15 & 60 & 60 & Melamine & 67 & 0.5 Fold & 10 & 30 & 4 & $7.14 \times 10^{2}$ & 5.21 & n.d. & 9.98 \\
\hline 16 & 60 & 60 & Porcelain & 33.5 & 0.5 Fold & 20 & 30 & 90 & $3.57 \times 10^{2}$ & 4.10 & n.d. & 9.16 \\
\hline 17 & 60 & 60 & Glass & 67 & 5 Fold & 5 & 45 & 4 & $71.36 \times 10^{2}$ & 4.33 & 1.16 & 10.65 \\
\hline 18 & 60 & 60 & Melamine & 6.7 & 1 Fold & 10 & 15 & 25 & $1.43 \times 10^{2}$ & 2.22 & 1.32 & 12.95 \\
\hline
\end{tabular}

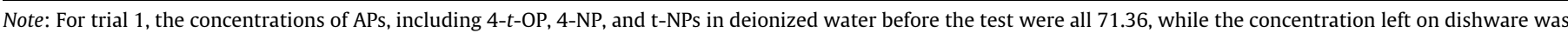

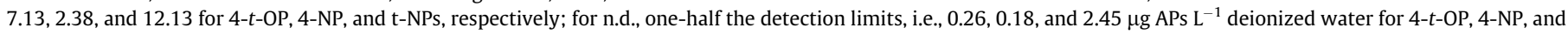
t-NPs, respectively, was assigned for the analysis by the Taguchi method.

${ }^{\text {a }}$ Food detergent with no APs detected was used as the media in the test; detergent sample diluted to $6.7 \mathrm{~g} \mathrm{~L}^{-1}$ with methanol was suggested by CNS 3800 , Taiwan (CNS Standards, 2000); higher concentrations (33.5 and $67 \mathrm{~g} \mathrm{~L}^{-1}$ ) were also prepared for the test.

${ }^{\mathrm{b}}$ Highest concentration of alkylphenols determined from 75 food detergents was selected as the reference concentration, i.e., $2.13 \times 10^{-3}$ (APs/detergent, mg $\mathrm{g}^{-1}$ ); the $\mathrm{APs}$ was spiked after the detergent media (with no APs detected as mentioned above) was diluted with methanol.

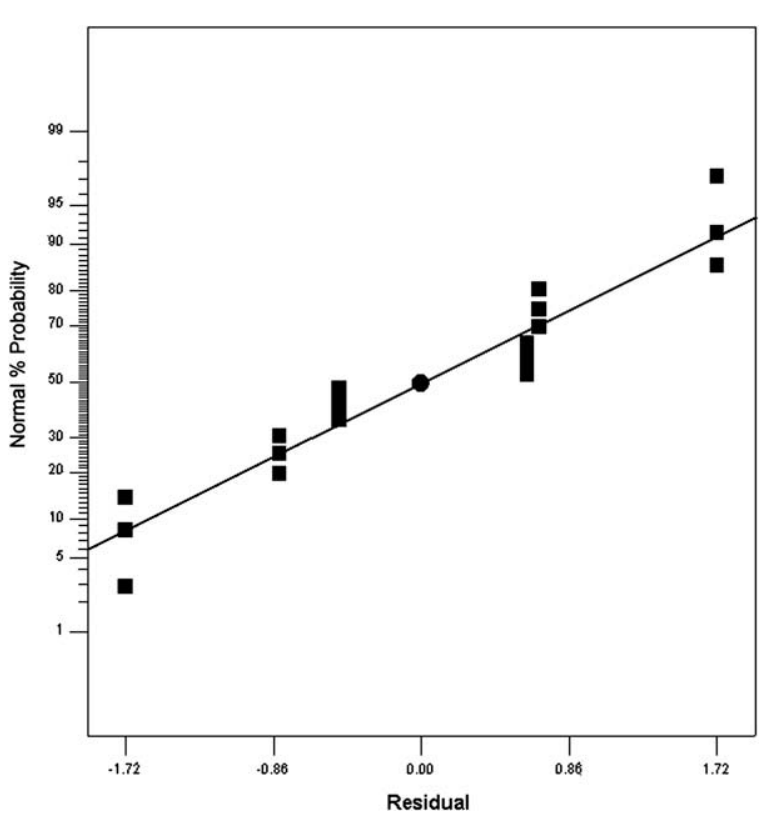

Fig. 2. Normal probability plot of the 4-t-OP residuals for dishware analysis. The $x$ axis, statistical residual, means the difference between the observed value and the value predicted by the model.

suggested that the 4-NPs left on the dishware will increase as the concentrations of detergents used increased.

For t-NPs, backward elimination procedure was also needed to be performed. The same as the results from 4-NPs, only the concentrations of detergents were kept in the model $(p=0.0071)$ while the t-NPs left on the dishware seemed to be increased as the concentrations of detergents applied increased.

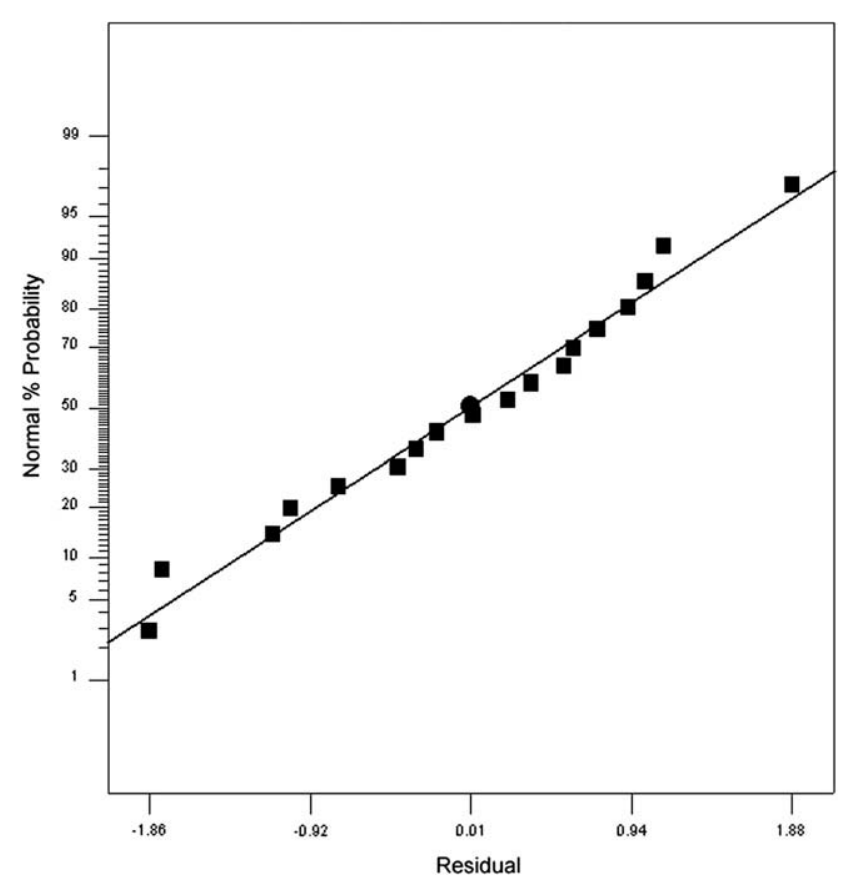

Fig. 3. Normal probability plot of the 4-t-OP residual for dishware analysis after backward elimination procedure. The $x$-axis, statistical residual, means the difference between the observed value and the value predicted by the model.

\subsection{Residual characteristics of alkylphenols on fruits from food detergents}

As shown in Table 4, fractional factorial design approaches were also applied to study the factors that might affect the residue of APs from food detergents on fruits, including the concentrations of APs spiked in food detergent, varieties of fruits, concentration 
Table 4

$\mathrm{L}_{9}\left(3^{4}\right)$ orthogonal array for residual characteristics determinations on fruits.

\begin{tabular}{|c|c|c|c|c|c|c|c|c|}
\hline \multirow[t]{2}{*}{ Trial } & \multirow[t]{2}{*}{ Fruits } & \multirow[t]{2}{*}{$\begin{array}{l}\text { Detergent } \\
\text { conc. }^{\mathrm{a}}\left(\mathrm{g} \mathrm{L}^{-1}\right)\end{array}$} & \multirow[t]{2}{*}{$\begin{array}{l}\text { Alkylphenols } \\
\text { conc. }^{\text {b }}\end{array}$} & \multirow[t]{2}{*}{$\begin{array}{l}\text { Immersion } \\
\text { time (min) }\end{array}$} & \multicolumn{4}{|c|}{$\begin{array}{l}\text { Note: APs in deionized water before the test } \\
\text { ( } \mu \mathrm{g} \mathrm{APs} \mathrm{L}^{-1} \text { deionized water) vs. APs left on fruits (ng APs } \mathrm{g}^{-1} \text { fruit) }\end{array}$} \\
\hline & & & & & APs & $4-t-O P$ & 4-NP & t-NPs \\
\hline 1 & Apple & 6.7 & 0.5 Fold & 5 & 71.36 & 1.51 & 1.51 & 5.39 \\
\hline 2 & Apple & 33.5 & 1 Fold & 10 & $7.14 \times 10^{2}$ & 2.22 & 0.95 & 4.73 \\
\hline 3 & Apple & 67 & 5 Fold & 20 & $71.36 \times 10^{2}$ & 3.25 & 2.75 & 14.09 \\
\hline 4 & Tomato & 6.7 & 1 Fold & 20 & $1.43 \times 10^{2}$ & 1.57 & 1.72 & 5.13 \\
\hline 5 & Tomato & 33.5 & 5 Fold & 5 & $35.68 \times 10^{2}$ & 3.62 & 3.45 & 5.51 \\
\hline 6 & Tomato & 67 & 0.5 Fold & 10 & $7.14 \times 10^{2}$ & 2.36 & 2.23 & 5.85 \\
\hline 7 & Grape & 6.7 & 5 Fold & 10 & $7.14 \times 10^{2}$ & 4.26 & 2.47 & 9.06 \\
\hline 8 & Grape & 33.5 & 0.5 Fold & 20 & $3.57 \times 10^{2}$ & 2.10 & 1.55 & 8.42 \\
\hline 9 & Grape & 67 & 1 Fold & 5 & $14.27 \times 10^{2}$ & 4.05 & 2.31 & 4.09 \\
\hline
\end{tabular}

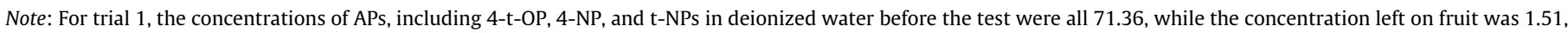
1.51 , and 5.39 for 4-t-OP, 4-NP, and t-NPs, respectively.

a Food detergent with no APs detected was used as the media in the test; detergent sample diluted to $6.7 \mathrm{~g} \mathrm{~L}^{-1}$ with methanol was suggested by CNS 3800 , Taiwan (CNS Standards, 2000); higher concentrations (33.5 and $67 \mathrm{~g} \mathrm{~L}^{-1}$ ) were also prepared for the test.

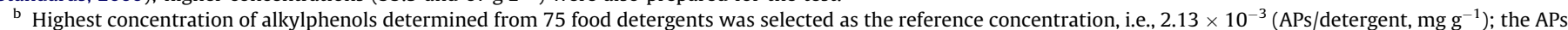
was spiked after the detergent media (with no APs detected as mentioned above) was diluted with methanol.

of surfactant, and time spent for the detergent soaking process on fruits.

In regard to t-NPs, backward elimination procedure was again used by the Design-Expert 7.0. However, the normal probability of residuals still showed the model did not have acceptable adequacy and a transformation was suggested. Data transformations by the Design-Expert, including square root, natural log, base 10 $\log$, and inverse sqrt were then performed following by the backward elimination procedure. Acceptable normality of residual analysis appeared when only the concentration of t-NPs spiked, the concentrations of detergents and the varieties of fruits were kept in the model $(p<0.0001)$ under square root transformation. The results suggested that different fruits seemed to have different tendencies of having t-NPs left on them $(p=0.001)$, while apples showed to be easier to have the left of t-NPs when compared with tomatoes and grapes. On the other hand, the t-NPs left on the fruits will increase as the concentration of detergents and the concentrations of t-NPs spiked increased.

Besides t-NPs, residual characteristics of 4-t-OP and 4-NP on fruits were also determined. The results suggested that there were no significant effects for the 4-t-OP and 4-NP left on fruits from the factors evaluated in this study.

\subsection{Maximum estimated dose of alkylphenols exposures from the use of household food detergents in Taiwan}

Maximum dose of daily APs exposures from the use of household food detergents in Taiwan was estimated in this study. The highest concentrations of APs found from the tests on residual characteristics were adopted for the worst-case calculations, and two possible sources of exposures were considered, including daily water consumption and fruits intakes. The daily water intake rate was assumed to be $2000 \mathrm{~mL} \mathrm{~d}^{-1}$ for adult with average body weight of $70 \mathrm{~kg}$ (Hallenbeck, 1993), while the average fruits intake rates in Taiwan were assumed to be $172.12 \mathrm{~g} \mathrm{~d}^{-1}$ and $208.28 \mathrm{~g} \mathrm{~d}^{-1}$ for male and female, respectively (Tzeng et al., 1999). The maximum dose of 4-t-OP, 4-NP and t-NPs exposures from water consumption was then estimated to be $0.275,0.106$, and $0.378 \mu \mathrm{g} \mathrm{d}^{-1}-\mathrm{kg}$, respectively. On the other hand, the maximum intakes of 4-t-OP from fruits were estimated to be 0.010 and $0.0126 \mu \mathrm{g} \mathrm{d}^{-1}-\mathrm{kg}$ for male and female in Taiwan, respectively. For 4-NP, the maximum intakes were estimated to be $0.008 \mu \mathrm{g} \mathrm{d}^{-1}$ $\mathrm{kg}$ for male, and $0.010 \mu \mathrm{g} \mathrm{d}^{-1}-\mathrm{kg}$ for female. For t-NPs, the maximum intakes were estimated to be $0.035 \mu \mathrm{g} \mathrm{d}^{-1}-\mathrm{kg}$ for male, and $0.042 \mu \mathrm{g} \mathrm{d}^{-1}-\mathrm{kg}$ for female.
Besides detergents, other sources might also cause the exposures of APs. For example, the daily intake of NP through various foodstuffs has also been determined for Taiwanese population, and the estimated dose was around $0.449 \mu \mathrm{g} \mathrm{d}^{-1} \mathrm{~kg}$ (assumed average body weight equal $70 \mathrm{~kg}$ ) (Lu et al., 2007). The oral no observed adverse effect level (NOAEL) for NP has been established to be $50 \mathrm{mg} \mathrm{d}^{-1} \mathrm{~kg}$ for rats (Cunny et al., 1997). As mentioned above, the maximum estimated dose of APs exposure, i.e., t-NPs, through both water consumption and fruit intakes in this study was around $4.20 \times 0^{-4} \mathrm{mg} \mathrm{d}^{-1} \mathrm{~kg}\left(0.378 \mu \mathrm{g} \mathrm{d}^{-1} \mathrm{~kg}+0.042 \mu \mathrm{g} \mathrm{d}^{-1}\right.$ $\mathrm{kg}$ ). The margin of exposure (MOE) can then be calculated as $50 /\left(4.20 \times 10^{-4}\right)=149047$. As for the safety factor, normally 500 or 1000 will be employed (Dayan, 2007). Whatever safety factor is used, the maximum dose of APs exposure estimated in this study is less than the NOAEL. Therefore, it is suggested that the presence of APs after detergent using will not present a health risk.

\section{Conclusions}

The results of the study demonstrated that alkylphenols were frequently detected from food detergents in Taiwan. Therefore, it can be expected that APs will also be detected in other aquatic environments. To assess the associate risks in Taiwan, the concentrations of alkylphenols in wastewater and other environmental media needed to be determined as well.

As for the residual characteristics, cleaning temperature was observed to have effect on the concentrations of 4-t-OP left on dishware, while the concentrations of detergents used will affect the left of t-NPs and 4-NP on dishware as well. On the other hand, including varieties of fruits, concentrations of surfactant and APs in detergents might have contributions to the left of t-NPs on fruits. It is suggested that proper instructions should be applied on the labels of the products to avoid possible exposures from overuse of detergents.

\section{Acknowledgement}

This study was supported by grant from the Department of Health, Executive Yuan, Taiwan (DOH95-TD-F-113-026).

\section{References}

Alben, K.T., 2002. Design, analyze, and optimize with design-expert. Anal. Chem. 74, 222A-223A. 
Cheng, C.Y., Ding, W.H., 2002. Determination of nonylphenol polyethoxylates in household detergents by high-performance liquid chromatography. J. Chromatogr. A 968, 143-150.

Cheng, C.Y., Wu, C.Y., Wang, C.H., Ding, W.H., 2006. Determination and distribution characteristics of degradation products of nonylphenol polyethoxylates in the rivers of Taiwan. Chemosphere 65, 2275-2281.

CNS Standards 3800, 2000. Synthetic detergent for food and kitchen utensil, Bureau of Standards, Metrology and Inspection, MOEA, Taiwan. (http://www.nsonline.com. tw/en/preview/preview.jsp?general_no=0380000\&anguage=C\&pagecount=7).

Cunny, H.C., Mayes, B.A., Rosica, K.A., Trutter, J.A., Van Miller, J.P., 1997. Subchronic toxicity (90-day) study with para-nonylphenol in rats. Regul. Toxicol. Pharmacol. 26, 172-178.

Dayan, A.D., 2007. Risk assessment of triclosan [Irgasa] in human breast milk. Food Chem. Toxicol. 45, 125-129.

Diaz, A., Ventura, F., Galceran, M.T., 2002. Development of a solid-phase microextraction method for the determination of short-ethoxy-chain nonylphenols and their brominated analogs in raw and treated water. J. Chromatogr. A 963, 159-167.

Environment Canada, 2001. Canadian Environmental Protection Act, Priority Substances List Assessment Report: Nonylphenol and its Ethoxylates.

European Commission Joint Research Center, 2002. European Union Risk Assessment Report, 4-Nonylphenol (branched) and Nonylphenol, 2nd Priority List, vol. 10, Luxembourg.

EU Cement Directive, 2003. Directive 2003/53/EC of the European Parliament and of the Council. Official Journal of the European Union, Luxembourg.

Gutendorf, B., Westendorf, J., 2001. Comparison of an array of in vitro assays for the assessment of the estrogenic potential of natural and synthetic estrogens, phytoestrogens and xenoestrogens. Toxicology 166, 79-89.

Hallenbeck, W.H., 1993. Quantitative Risk Assessment for Environmental and Occupational Health, second ed. Lewis Publishers, New York

Harris, R.M., Waring, R.H., Kirk, C.J., Hughes, P.J., 2000. Sulfation of "estrogenic" alkylphenols and 17beta-estradiol by human platelet phenol sulfotransferases. J. Biol. Chem. 275, 159-166.

Hicks, C.R., 1999. Fundamental Concepts in the Design of Experiments. Oxford University Press, New York.

Hoai, P.M., Tsunoi, S., Ike, M., Kuratani, Y., Kudou, K., Viet, P.H., Fujita, M., Tanaka, M. 2003. Simultaneous determination of degradation products of nonylphenol polyethoxylates and their halogenated derivatives by solid-phase extraction and gas chromatography-tandem mass spectrometry after trimethylsilylation. J. Chromatogr. A 1020 (2), 161-171.

Jobling, S., Sheahan, D., Osborne, J.A., Matthiessen, P., Sumpter, J.P., 1996. Inhibition of testicular growth in rainbow trout (Oncorhynchus mykiss) exposed to estrogenic alkylphenolic chemicals. Environ. Toxicol. Chem. 15, 194-202.

Lara-Martin, P.A., Gomez-Parra, A., Gonzalez-Mazo, E., 2008. Reactivity and fate of synthetic surfactants in aquatic environments. Trac-Trend. Anal. Chem. 27, 684-695.
Latorre, A., Lacorteb, S., Barcelo, D., Montury, M., 2005. Determination of nonylphenol and octylphenol in paper by microwave-assisted extraction coupled to headspace solid-phase microextraction and gas chromatographymass spectrometry. J. Chromatogr. A 1065, 251-256.

Lu, Y.Y., Chen, M.L., Sung, F.C., Wang, P.S., Mao, I.F., 2007. Daily intake of 4 nonylphenol in Taiwanese. Environ. Int. 33, 903-910.

Madsen, S.S., Skovbolling, S., Nielsen, C., Korsgaard, B., 2004. 17-Beta estradiol and 4-nonylphenol delay smolt development and downstream migration in Atlantic salmon, Salmo salar. Aquat. Toxicol. 68, 109-120.

Montgomery, D.C., 2001. Design and Analysis of Experiments, fifth ed. Wiley, New York.

Pan, Y.P., Tsai, S.W., 2008. Solid phase microextraction procedure for the determination of alkylphenols in water by on-fiber derivatization with $\mathrm{N}$-tertbutyl-dimethylsilyl- $N$-methyltrifluoroacetamide. Anal. Chim. Acta 624, 247252.

Peng, X., Wang, Z., Yang, C., Chen, F., Mai, B., 2006. Simultaneous determination of endocrine-disrupting phenols and steroid estrogens in sediment by gas chromatography-mass spectrometry. J. Chromatogr. A 1116, 51-56.

Renner, R., 1997. European bans on surfactant trigger transatlantic debate. Environ. Sci. Technol. 31, 316A-320A.

Sakurai, K., Sugaya, N., Nakagawa, T., Uchiyama, T., Fujimoto, Y., Takashi, K., 2005 Simultaneous analysis of endocrine disruptors, 4-alkylphenol and bisphenol A contained in synthetic resin products used for drug containers and household utensils. J. Health Sci. 51, 538-548.

Shih, C.R., 1997. Survey of surfactant industries in Taiwan. Chem. Technol. 5, 112117 (Taiwan; in Chinese).

Soto, A.M., Sonnenschein, C., Chung, K.L., Fernandez, M.F., Olea, N., Serrano, F.O. 1995. The e-screen assay as a tool to identify estrogens: an update on estrogenic environmental pollutants. Environ. Health Persp. 103, 113-122.

Tsai, S.W., Shih, M.W., Pan, Y.P., 2008. Determinations and residual characteristics of triclosan in household food detergent of Taiwan. Chemosphere 72, 12501255.

Tzeng, M.S., Kao, M.D., Yeh, W.T., Pan, W.H., 1999. Food consumption frequency and eating habit among Taiwanese-NAHSIT 1993-1996. Nutr. Sci. J. 24, 59-80 (Taiwan).

United Kingdom Environment Agency (UKEA), 2005. Environmental Risk Evaluation Report: 4-tert-Octylphenol. US Code of Federal Regulations, Title 40, Part 136 , Appendix B, Definition and Procedure for the Determination of the Method Detection Limit, Revision 1.11.

Xie, Z., Selzer, J., Ebinghaus, R., Caba, A Ruck, W. 2006. Development and validation of a method for the determination of trace alkylphenols and phthalates in the atomosphere. Anal. Chim. Acta 565, 198-207.

Ying, G.G., Williams, B., Kookana, R., 2002. Environmental fate of alkylphenols and alkylphenol ethoxylates - a review. Environ. Int. 28, 215-226.

Ying, G.G., 2006. Fate, behavior and effects of surfactants and their degradation products in the environment. Environ. Int. 32, 417-431. 